\title{
PLATT: A flexible platform for experimental research on team performance in complex environments
}

\author{
WIM KaMPHUIS \\ TNO Defence, Security and Safety, Soesterberg, The Netherlands \\ and Tilburg University, Tilburg, The Netherlands \\ Peter J. M. D. Essens And Kees Houttuin \\ TNO Defence, Security and Safety, Soesterberg, The Netherlands \\ AND \\ ANTHONY W. K. GAILlaRd \\ TNO Defence, Security and Safety, Soesterberg, The Netherlands \\ and Tilburg University, Tilburg, The Netherlands
}

\begin{abstract}
The present article introduces PLATT, a recently developed task environment for controlled experimental research on team performance in complex environments. PLATT was developed to meet the research demands posed by the complexity that present-day teams face. It consists of a flexible, modular software architecture and research-specific scenarios. The scenarios can target various types of tasks (e.g., planning, problem solving, and decision making) in different operational contexts. Different software configurations can be used to investigate questions pertaining to team structure, team virtuality, and multiteam systems. We describe the software architecture, one of the scenarios, and the broad range of automated and embedded measurement possibilities that PLATT offers. To illustrate PLATT's possibilities, in the present article, we describe a number of experiments that have used PLATT for a variety of research questions. We conclude that PLATT meets the formulated research demands and provides researchers with a flexible platform to investigate the complex issues that present-day teams face.
\end{abstract}

Teams are everywhere. They can accomplish tasks that exceed the capabilities of single individuals. In our age of information, teams have to be able to cope with an increasingly complex world. Large amounts of information, with an often ambiguous and contradictory nature, tax the abilities of teams. They have to be effective in dynamic and unpredictable environments. To complicate matters even more, team members may be geographically dispersed, necessitating the use of technology to communicate with each other.

The complexity that present-day teams have to meet requires scientific understanding (see Salas, Cooke, \& Rosen, 2008). Research is needed that aims to gain more insight into the present-day factors affecting team effectiveness, in order to contribute to the development of training methods, interventions, and technology to improve their effectiveness. Studies with existing teams in field settings can provide initial insights in the conditional factors of teamwork. In order to test predictions derived from these field studies systematically and to establish causal relationships, more controlled experimentation is necessary. For these studies, experimental team tasks are necessary. On the one hand, these tasks have to embody the complexity that present-day teams face. Only then can relevant processes emerge and be measured. On the other hand, these tasks have to allow a good degree of control. Only then can processes of interest be measured in a systematic way. Hence, there is a complexity-control tradeoff. The present article describes a recently developed task environment that facilitates controlled experimental research on team performance in complex environments: PLATT (the "planning task for teams"1).

\section{PREVIOUS RESEARCH}

Team researchers have conducted research on both ends of the simplicity-complexity continuum. They have used either simple tasks in highly controllable laboratory experiments or complex tasks in realistic, high-fidelity simulations. As an example of a simple task that has been used for the study of team performance, consider the "winter survival exercise" (Johnson \& Johnson, 1987), in which

W. Kamphuis, wim.kamphuis@tno.nl 
participants have to reach a consensus concerning the ranking of 12 items salvaged from a crashed plane, according to their relative survival value (see, e.g., Durham, Locke, Poon, \& McLeod, 2000). High-fidelity simulations to study team performance are, for example, business management simulations such as "Tycoon," developed by the Amos Tuck School of Business Administration in 1973 (see, e.g., Gladstein \& Reilly, 1985), or the "Management Game" (MCC, 1993; see, e.g., Van der Vegt \& Van de Vliert, 2005).

Although both types of research can deliver valuable knowledge, the tasks used seem to be less useful in light of the mentioned team research needs of complexity and controllability. With the simple team tasks, the complexity that present-day teams face cannot be investigated. In addition, many of the processes that are characteristic of teams are absent in these tasks because of a lack of inherent role differentiation. The high-fidelity simulations elicit real team behavior, but do not provide enough experimental control.

A more recent approach that is positioned between these two ends is the use of low-fidelity simulations: networked multiplayer computer games that reflect reality to a certain degree, but still offer control (Weaver, Bowers, Salas, \& Cannon-Bowers, 1995). The past quarter century produced a wealth of low-fidelity networked computer simulations. Consider, for example, the Distributed Dynamic DecisionMaking Simulation (DDD; Kleinman, Serfaty, \& Luh, 1984), the Team Interactive Decision Exercise for Teams Incorporating Distributed Expertise (TIDE2; Hollenbeck, Sego, Ilgen, \& Major, 1991), the Tactical Navy Decision Making task (TANDEM; Weaver et al., 1995), the Team Performance Assessment Battery (TPAB; see Weaver et al., 1995), Team-Track (Jentsch, Bowers, Compton, Navarro, \& Tait, 1996), Argus (Schoelles \& Gray, 2001), C3Fire (Granlund, 2002), and the Fire Fighting Team Task (FFTT; Rasker, 2002). All of these tasks are, in essence, monitoring tasks in which targets have to be monitored or detected, and subsequently correctly dealt with. Team members repeatedly have to bring together distributed information about these targets, make decisions concerning these targets, and take appropriate actions.

This category of tasks makes it possible to investigate real team behavior under controlled conditions. The focus of these tasks, however, is on the action aspects of team performance. Since judgments and decisions in these tasks are rule based and become routine, few higher level, nonroutine, problem-solving processes are demanded. Weaver et al. (1995) already noted that, although these simulations appear quite dynamic, in reality they do not allow for much complexity, since the actions required from the team members are repetitive in nature and their roles are too well defined. Consequently, these low-fidelity simulations do not fully satisfy the mentioned team research needs, since these needs also pertain to higher level, complex problem-solving aspects of team performance (cf. Salas et al., 2008).

\section{PURPOSE AND REQUIREMENTS}

Since none of the aforementioned approaches seemed to be able to fully address the complexity that present-day teams face in a controlled setting, we decided to develop a new task environment. This task environment had to initiate a research program on team performance in a complex, networked world. The environment had to permit controlled experimental team research on complex planning and problem-solving behavior. In terms of the described approaches, the environment was to be positioned between the low- and high-fidelity simulations.

Specifically, we formulated seven requirements that the task environment had to fulfill (see also Kamphuis \& Houttuin, 2007). First, participants performing the task should exhibit real team behavior. In line with Salas, Dickinson, Converse, and Tannenbaum (1992), we defined teams as distinguishable sets of individuals who have each been assigned specific roles or tasks to perform and who work interdependently toward a common goal. The most important necessity stemming from this definition is that the task should have a division of roles with different specializations, leading to interdependence among team members to reach the common goal.

Second, the task environment should be suited to study the higher level team processes that surface in complex environments. The task, therefore, should have a high level of complexity. Although task complexity is difficult to define, researchers (e.g., Brown \& Miller, 2000; Kelly, Futoran, \& McGrath, 1990; Rasmussen, 1986; Staw, Sandelands, \& Dutton, 1981; Volkema, 1988; Wood, 1986) have identified a number of attributes that contribute to the complexity of a task, including:

- The information load (the sheer amount of information that must be processed to successfully complete the task, and the number of different information sources);

- The number of subtasks (the number of acts requiring specific knowledge and skills that must be carried out to accomplish the task);

- Unfamiliarity and nonrepetitivity (the extent to which well-learned skills or procedures to perform the task are lacking);

- Task uncertainty (the ambiguity of information in the task, the lack of knowledge concerning the relationship between processes and outcomes, and the novelty of potential outcomes);

- The number of goals or pathways to goals;

- Time-varying conditions (relating to the dynamic nature of the task environment, with changing circumstances and rules).

In team tasks, interdependence among team members adds to the task complexity. The task environment should be constructed in such a way that it scores high on these attributes. Only then will teams need to demonstrate higher level team processes (such as information search and selection, hypothesis generation, planning and replanning, priority setting, and problem solving) to accomplish their task.

Third, the task environment should offer a good degree of experimental control. It should be possible to keep all circumstances constant across teams, including the events in the task. The task, therefore, should be dynamic only with 
respect to scripted changes, not with respect to participants' actions. In this way, differences in processes and effectiveness can be attributed solely to experimental manipulations.

Fourth, the task environment should allow relatively efficient data collection. More precisely, it should be possible to perform the task without specific foreknowledge and without extensive training in a relatively short amount of time, and the task should be capable of being constructed in multiple comparable versions (to enable within-team designs and practice rounds).

Fifth, the task environment should offer a broad range of team process measurement possibilities, both behavioral and self-report. It should be capable of taking unobtrusive, real-time automated behavioral measures (see Salas et al., 2008) and should collect these in a single log file. In addition, it should offer the possibility of online, embedded questionnaires that have to be filled out during task performance. The task environment should allow the measurement of team cognition (see, e.g., CannonBowers, Salas, \& Converse, 1993; Klimoski \& Mohammed, 1994).

Sixth, the software should allow a high degree of flexibility. Much of the existing team research software is intended for investigating specific research questions and does not leave much room for alterations in configuration (see, e.g., Kerr, Aronoff, \& Messé, 2000). As a result of this, experimenters frequently have to develop their own software to be able to investigate a specific research question. The present task environment should address this problem and have a generic structure that can be tailored to specific research questions. It should be possible to investigate a wide array of research questions within the same task environment. The task environment should, for example, be suitable for multiteam systems research (Mathieu, Marks, \& Zaccaro, 2001) and allow larger numbers of players, the configuration of multiple teams, and multiple hierarchical levels.

Finally, the task environment should have a good degree of usability. This usability pertains to two groups of users. First, the task environment should be easy to learn and to use for participants performing the experimental tasks (also see requirement four above). Second, the task environment should be easy to use for experimenters wanting to use it to investigate their own research questions.

\section{PLATT}

In response to these aforementioned requirements, we developed PLATT, a flexible software platform for controlled experimental research on team performance in complex environments. PLATT consists of a modular software architecture in which research-specific scenarios can be run. The software architecture is research question independent and guarantees a large degree of flexibility. The scenarios are developed on the basis of a theorybased research model, in response to specific research questions. Participants playing the scenarios receive messages, search for information on Web sites, interact with a shared workspace, and communicate with each other via e-mail. The scenarios can target different types of tasks, such as planning, problem solving, and decision making. Moreover, the scenarios can take place in different operational contexts - for example, the military, organizational settings, or crisis management contexts. There is no limit to the number of participants that can join in a scenario.

\section{Software Architecture}

The PLATT software architecture (see Figure 1) is a distributed application. It consists of a scenario player, a Web agent, and a participant interface with different components. In addition, there is a separate data analysis tool. PLATT has been created using the JADE agent platform. JADE (Bellifemine, Caire, Poggi, \& Rimassa, 2003) is a widespread agent-oriented middleware system that is distributed as open-source software under LGPL license. All distributed parts of PLATT (i.e., scenario player, Web agent, and participant interface) are implemented as JADE agents that communicate using the JADE communication infrastructure.

The scenario player reads the configuration file and the scenario file. During an experiment, the scenario player sends scenario events to the team members and defines changes on the Web sites that they can visit. It also creates a $\log$ file with detailed information of all scenario events and of all actions that participants perform during task execution (i.e., sending, opening, and receiving e-mails, selecting Web browser or shared workspace tabs, opening Web pages, etc.; see the Appendix for an excerpt of an actual $\log$ file).

The Web agent keeps track of the access rights of different participants to Web pages and registers the current version of a page. Information on Web pages can be made dynamic (i.e., changing over time) by creating different versions of the same page and having the scenario define which version of a page should be available at what moment. When the Web server receives a page request from a participant (via the Web browser), it consults the Web agent and handles the request in accordance with the access rights and the version information of the Web page. If the participant has the proper access rights, the browser shows the requested page in return.

Finally, the participant interface shows the different applications that participants can use during the scenario. It consists of multiple windows positioned on top of each other. In the standard PLATT setup, the participant interface contains three windows: an e-mail window, a Web browser window, and a shared workspace window.

When participants open their e-mail window (see Figure 2), they can use an e-mail application to communicate with each other via text messages. This communication is not bound by any restrictions. In the e-mail application, team members also receive the scripted events from sources in the scenario, sent by the scenario player. The scripted events that they receive can have different formats. It can be a text message, an audio message, a video message, or a hyperlink to a Web page.

In the Web browser window (see Figure 3), participants can search for additional information. This information is 


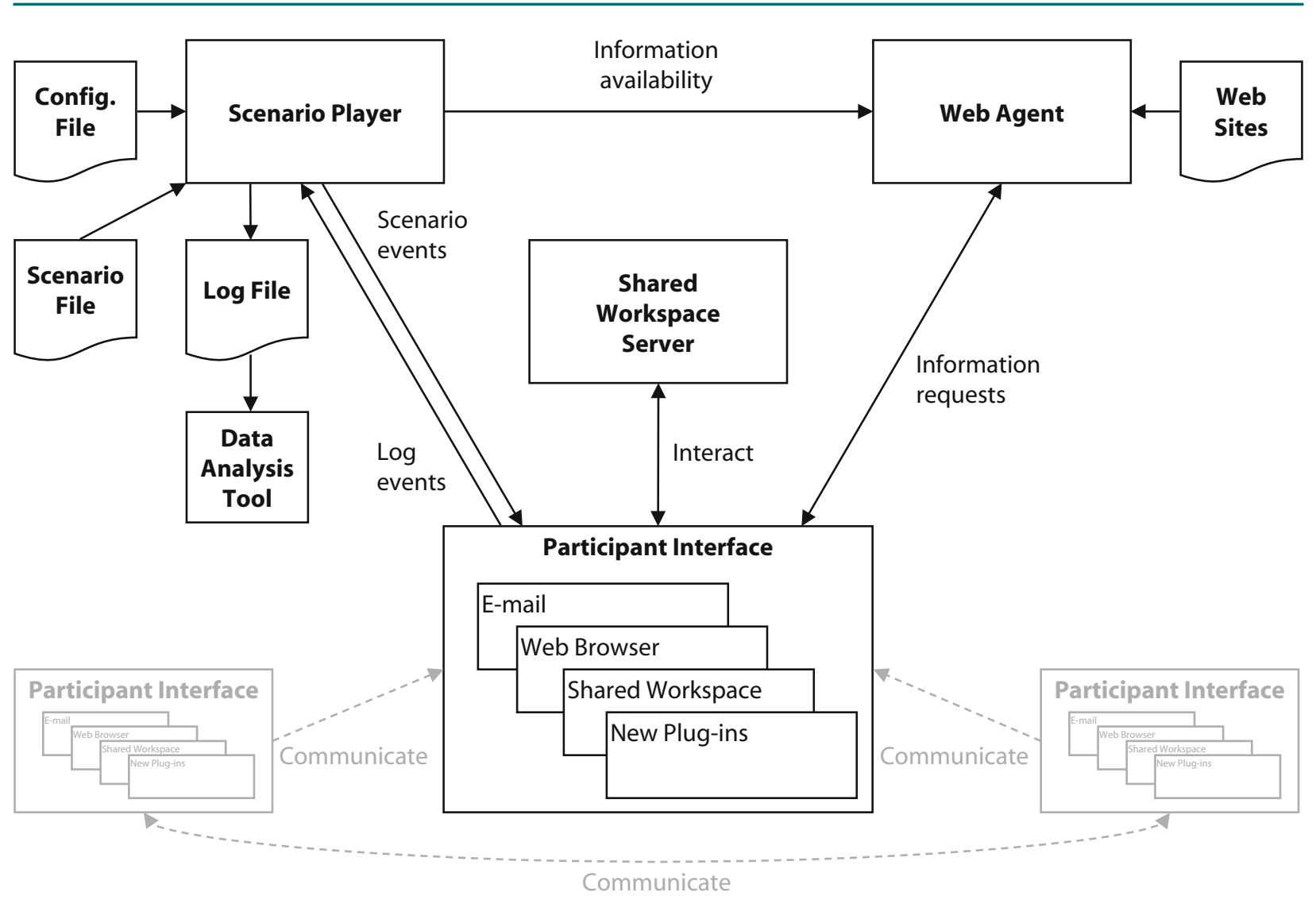

Figure 1. Schematic overview of the PLATT software architecture.

part of the scenario, and the scenario controls which information is available at what moment. The browser allows for the presentation of virtually any textual, visual, and multimedia content. Because of this, the scenario content can be as rich as the content that can be found on the Internet.
The last window is the shared workspace window (see Figure 4). The shared workspace is a digital area that allows for parallel viewing and editing by team members with the appropriate authorization. In this space, team members may work jointly on certain team tasks. The

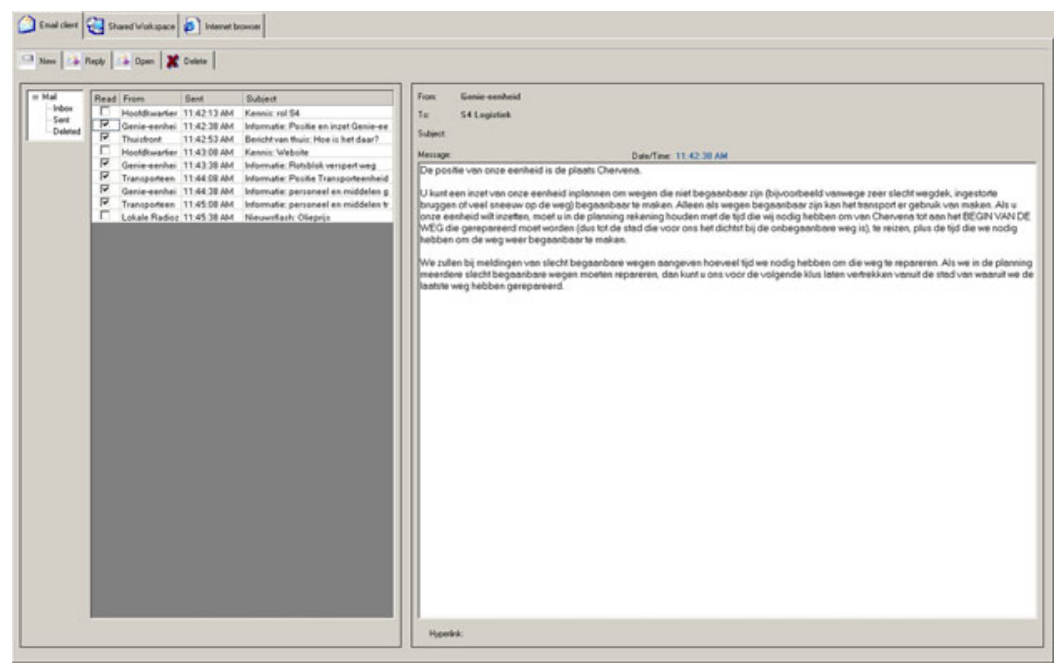

Figure 2. Participant interface with the e-mail window opened. The other two applications (Web browser and shared workspace) can be opened by clicking the tabs in the upper left corner. 


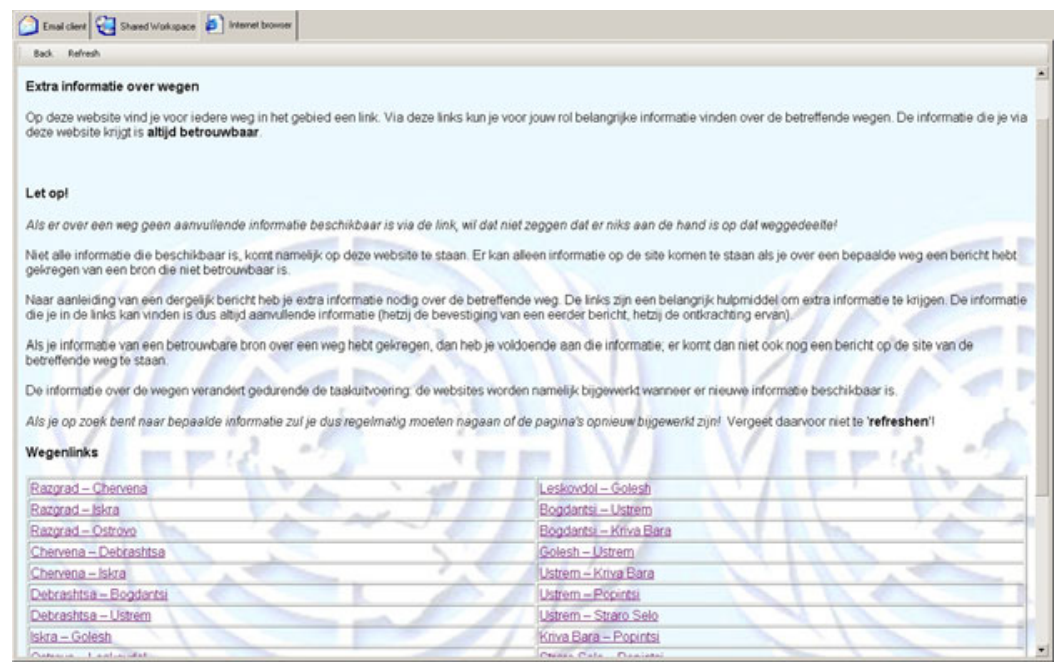

Figure 3. Participant interface with the Web browser window opened. The picture displays one of the Web sites of the military evacuation scenario (described below). This Web site contains links for all of the roads that run between cities in the area in which an evacuation has to be planned. The links can be clicked to search for information concerning the condition of these roads. This information can be dynamic (i.e., changing over time).

shared workspace may also act as a common operational picture that is constantly being updated according to changes in the situation.

The client software has a modular design that has been established using a component framework. All participant applications (e.g., e-mail, Web browser, shared workspace) are independent PLATT components that can be plugged into the framework and configured in the central configuration file. Every component is loaded on a new tab in the participant interface. This plug-in architecture makes it relatively easy for researchers to extend PLATT with new components using the framework software interface. Different kinds of shared workspaces have already been implemented and used in experiments (e.g., a digital editable map, a bulletin board for sharing e-mails, and a shared whiteboard). Similarly, different kinds of communication media could be plugged in (e.g., chat or video conferencing), and different Web browsers could be used. This modular design contributes to the flexibility of the PLATT software platform.

The data analysis tool supports data analysis in Excel by a series of macros that aid in extracting meaningful measures from log files (e.g., total number of unopened e-mails as a measure of information selection). These macros are based on a query language and allow for defining custom (composite) events. The macros use the directory with the log files of all experimental runs as input and deliver one Excel sheet with query results as output. In this way, a summary sheet with individual, team, and total summaries can be easily constructed.

The complete configuration of an experiment is captured in a single file. This file defines the roles of participants, the communication structure of the team (or teams), and the interface components that each participant receives. The file also defines what computer is assigned to what role. Using this information, the scenario player controls the starting, running, and stopping of all remote clients, making it no longer necessary to perform these actions at every separate participant workstation during the experiment.

\section{Scenarios}

The scenarios that run in the software architecture are composed of a scenario file, content for the Web sites, and content for the shared workspace (e.g., a map of the area). Researchers can fill these components with their own content to create the type of task and operational context necessary to investigate their own specific research questions. No programming knowledge is required, since the scenario files can be written in Excel format (spreadsheets; see Table 1 for an excerpt of an actual scenario file) and content for the Web sites can be created using standard word processors. Scenarios can be tested by using the accelerate function of the scenario player. In this modus, the scenario unfolds at 10 times the normal speed. This allows the experimenter to ensure that all events occur at the expected time, that hyperlinks direct to the right pages, that questionnaires automatically pop up, and so forth.

Scenario files consist of predefined events on a linear time line. In the scenario file, every line is one event. The events fall into three categories. The first category of events consists of messages from sources in the scenario (e.g., "chief of staff" or "local radio station") that are sent to the participants. These messages can have text, audio, or video formats, and they may contain hyperlinks to Web pages. For each event, the experimenter defines the following in the scenario file: the time at which the event should start, the sender of the message (i.e., the scenario source), the recipient of the event (i.e., one or more of 


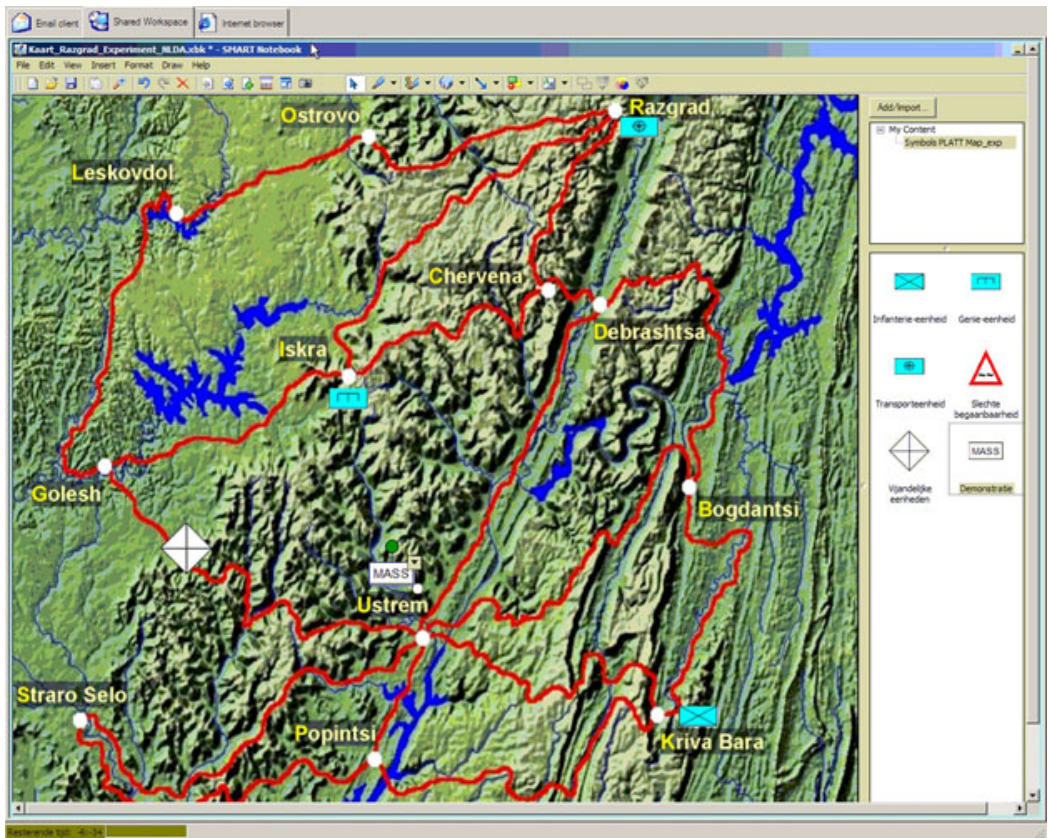

Figure 4. Participant interface with the shared workspace window opened. The picture displays the shared workspace of the military evacuation scenario. The symbols on the right-hand side can be used to represent specific information in the map.

the participants), the subject of the message, the message content, and, if applicable, the hyperlink that comes with the message (see, e.g., the first four events in Table 1).

The second category consists of changes in the information that can be found on the (scenario-specific) Web sites. In the scenario file, the experimenter can define which version of a Web page has to be accessible at what moment. In this way, the same page can show different information at different moments. For these events, the experimenter has to define the time, the recipient (who is allowed to visit this Web page), and the hyperlink to the Web page with the version number of this page (see Table 1, minutes 00.12, 00.13, and 00.14).

The last category of events in the scenario file consists of hyperlinks that open automatically when the participant receives the link. This category is used for the online questionnaires that participants have to fill out during the task. For these events, the experimenter also has to define the time, the recipient, and the hyperlink (see Table 1, second to last line).

\section{Research Model}

The development of a scenario is guided by the research model. The purpose of this model is to secure that the intended research will be about real team behavior, that it will be possible to measure relevant team processes, and that there will be a meaningful link between these processes and the team's performance. First, in order to measure real team behavior, there has to be task and goal interdependence between participants (for a taxonomy of different classes of interdependence, see Saavedra, Earley, \& Van Dyne, 1993). In a scenario, the experimenter has to realize this by creating different roles with different re- sponsibilities, expertise, and tasks, for each of the team's members. In addition, the quality of the output of the team's performance on the scenario has to be dependent on the input from every team member. The preconditions for team processes to emerge are fulfilled when the expertise from all team members is necessary to accomplish the task and when members are motivated to perform well as a team.

Second, the experimenter has to determine what team and task processes are of interest, given the research question, and how these processes can be elicited by the scenario. For example, if one is interested in backing up behavior, the scenario should incorporate situations or events in which there is an opportunity for team members to assist fellow team members with their task. This opportunity could be created by overloading one of the roles with information at a certain moment, while giving a fellow team member at that same moment the time and means to step in and help out. In addition, engaging in these processes needs to be relevant in view of the overall goal, because otherwise team members would not be required to demonstrate them.

Third, the experimenter has to think about ways to make the relevant processes measurable. This can be done at the behavioral level by, for example, designing critical events (events that need to be dealt with in a specified way) and by investigating how participants dealt with these events on the basis of the log file. It can also be done at the cognitive level by integrating online measurement techniques.

Finally, the experimenter should choose performance measures that are appropriate operationalizations of the overall goal. These operationalizations should be proximal 
Table 1

Excerpt of the Scenario File of a Military Evacuation Scenario

\begin{tabular}{|c|c|c|c|c|c|}
\hline Time & Sender & Recipient & Subject & Message & Hyperlink \\
\hline 00.10 .30 & Local civilians & Intelligence & $\begin{array}{l}\text { Information: } \\
\text { Rebels in the } \\
\text { west }\end{array}$ & $\begin{array}{l}\text { Today, our cousin travelled from Iskra to Golesh. At the } \\
\text { river, he was shot at by a sniper. He barely managed to es- } \\
\text { cape. It is advisable to avoid this road. }\end{array}$ & \\
\hline 00.11 .00 & Patrol & Intelligence & $\begin{array}{l}\text { Information: } \\
\text { Rocket } \\
\text { launchers }\end{array}$ & $\begin{array}{l}\text { At the northern part of the road between Debrashtsa and Us- } \\
\text { trem, we observed a group of } 20 \text { rebels, some of which were } \\
\text { carrying rocket launchers. If you want to make use of this } \\
\text { road for the evacuation, you will need to plan a deployment } \\
\text { of the infantry unit to clear this part of the route. }\end{array}$ & \\
\hline 00.11 .00 & $\begin{array}{l}\text { Local radio } \\
\text { station }\end{array}$ & Logistics & $\begin{array}{l}\text { Weather } \\
\text { report }\end{array}$ & $\begin{array}{l}\text { In the north, heavy snowfall occurred in the mountains. As } \\
\text { a consequence, some roads may have become obstructed. } \\
\text { At this moment, more accurate information can not be } \\
\text { provided. }\end{array}$ & \\
\hline 00.11 .00 & Home & Operations & $\begin{array}{l}\text { Home front: } \\
\text { Everything ok }\end{array}$ & $\begin{array}{l}\text { Hi there! How are you? Here everything is all right. We } \\
\text { hope to hear from you soon . . }\end{array}$ & \\
\hline 00.12 .00 & & Intelligence & & & $\begin{array}{l}\text { roads/RoadLG_2 } \\
\text { htm }\end{array}$ \\
\hline 00.12 .30 & $\begin{array}{l}\text { Transportation } \\
\text { unit }\end{array}$ & Logistics & $\begin{array}{l}\text { Informa- } \\
\text { tion: Loss of } \\
\text { vehicle }\end{array}$ & $\begin{array}{l}\text { One of our transportation vehicles broke down. Sadly, it is } \\
\text { not possible to repair this vehicle. }\end{array}$ & \\
\hline 00.13 .00 & & Intelligence & & & $\begin{array}{l}\text { roads/RoadIG_2 } \\
\text { htm }\end{array}$ \\
\hline 00.13 .30 & $\begin{array}{l}\text { Local radio } \\
\text { station }\end{array}$ & Intelligence & $\begin{array}{l}\text { News flash: } \\
\text { Demonstration }\end{array}$ & $\begin{array}{l}\text { On the road between Kriva Bara and Popintsi, a large crowd } \\
\text { demands president Tsankov's resignation. For the time } \\
\text { being, the demonstration is peaceful. However, motorists } \\
\text { making use of this road should already expect a delay of } 45 \\
\text { minutes. }\end{array}$ & \\
\hline 00.13 .30 & Patrol & Logistics & $\begin{array}{l}\text { Information: } \\
\text { Pass taken }\end{array}$ & $\begin{array}{l}\text { The pass between Ustrem and Straro Selo that seemed to } \\
\text { have been taken by the rebels, proves to be entirely safe. }\end{array}$ & \\
\hline 00.14 .00 & Local civilians & Intelligence & $\begin{array}{l}\text { Information: } \\
\text { Rebels in the } \\
\text { east }\end{array}$ & $\begin{array}{l}\text { In the east, between Debrashtsa and Bogdantsi, rebels have } \\
\text { been spotted. This road seems not to be safe anymore. }\end{array}$ & \\
\hline 00.14 .00 & & All & $\begin{array}{l}\text {-Question- } \\
\text { naire- }\end{array}$ & & $\begin{array}{l}\text { http://tmquest } \\
\text {.tm.tno.nl/ }\end{array}$ \\
\hline 00.14 .30 & Chief of staff & Operations & $\begin{array}{l}\text { Information: } \\
\text { Replacement }\end{array}$ & $\begin{array}{l}\text { The replacement of your troops will probably be delayed. } \\
\text { There is a chance that you will have to stay in the area for } \\
6 \text { instead of } 4 \text { months. }\end{array}$ & \\
\hline
\end{tabular}

to the processes of interest rather than distal to it, to assure a meaningful link between processes and performance.

\section{Scenario Example}

As an example of a scenario that has been developed for PLATT, we describe a military evacuation scenario that has been used in a series of studies with military personnel and with civilians (see, e.g., Kamphuis, Gaillard, \& Vogelaar, 2008, 2009).

Task. In this scenario, participants receive the assignment to develop a plan to evacuate a group of people from a hostile area to a safe place. More than a dozen routes can be used for the evacuation. The team has to determine the fastest route and plan how they will employ their transportation, engineer, and infantry units. Whether a route is appropriate depends not only on the length of the roads, but also on the condition of these roads, and whether there are enemy activities on these roads.

Roles. The scenario contains three roles, each of which has its own responsibilities, expertise, and tasks: Operations, Intelligence, and Logistics. Operations has the leadership role and is responsible for coordinating the activities of the other team members. Operations is the only team member who is allowed to edit the shared map of the area in which the evacuation has to take place. Intelligence is responsible for all safety information and has unique expertise concerning determining the reliability of all information sources in the scenario. Logistics is responsible for personnel and materiel, and for the condition of the roads. Logistics has unique expertise concerning calculating the duration of the various routes. Every team member receives role-specific training.

Instruction. Teams receive approximately $30 \mathrm{~min}$ of instruction. This instruction consists of a 20-min standard video with information about the team's assignment and the use of the participant interface. Afterward, team members receive a written instruction containing information about their own roles in the scenario. Every team member receives a different instruction, with role-specific knowledge and information.

Events. During the scenario, the team receives a large amount of information concerning road conditions, enemy 
activities, delays due to different causes, the position of their units, personnel and materiel problems, weather conditions, unrelated events, and so forth. This information varies in relevance and is sent by many sources differing in reliability. The information can be ambiguous, or in contradiction with information the team received earlier. The events in the scenario are constructed in such a way that at different moments, different routes are optimal, so the team has to adjust initial plans and adapt to circumstances

Web sites. Both Intelligence and Logistics have access to Web sites. Intelligence can search this Web site for information concerning the safety of the roads in the area. Logistics has a Web site containing information about the availability and the capacity of the units and the condition of the roads (see Figure 3). The scenario file controls changes in information on these Web sites.

Shared workspace. The shared workspace in this scenario consists of a digital, editable map of the area in which the evacuation has to take place (see Figure 4). All three roles can view this map, but only Operations is allowed to edit it. Operations can put symbols in the map to indicate, for example, enemy activities, locations of units, and road conditions. In addition, Operations can use text to "write" information in the map. These map updates are visible to Intelligence and to Logistics.

\section{POTENTIAL RESEARCH APPLICATIONS}

Because PLATT makes it possible to write new scenarios for every specific research question, the opportunities to investigate team performance in complex environments are numerous. Already, scenarios have been developed for investigating team processes in complex problem-solving tasks, networked decision-making tasks, and crisis management tasks. In addition to having the capability to write different scenarios or to adjust existing scenarios for different research questions, experimenters also have the ability to choose different software configurations to investigate their research questions. The PLATT software ensures a large degree of flexibility due to its modular structure. Below, we give three examples of theoretically and practically relevant manipulations that are based on the software configuration.

\section{Team Structure}

In PLATT, it is possible to manipulate the team's structure by defining who can communicate with whom. In this way, different team structures can be compared with each other. For example, it is possible to compare centralized team structures to decentralized team structures. Such a manipulation has relevance in light of the possibilities created by current information and communication technologies. Currently, lower levels in organizations ("the edges") can easily have all of the information necessary to make their own decisions at their disposal. Power and decision rights, therefore, could be given to these edges of the organization (Alberts \& Hayes, 2003), leading to decentralized organization structures. By simulating these circumstances in PLATT - decision speed, accuracy, and effectiveness, as well as other team measures (e.g., trust, shared awareness, and leadership) in self-organizingedge team structures could be compared with traditional hierarchical team structures.

This functionality of PLATT is comparable to the characteristics of another recently developed software environment for team research called ELICIT ("experimental laboratory for investigating collaboration, informationsharing, and trust"; Ruddy, 2006, 2007). ELICIT was developed to compare traditional command-and-control, hierarchical organizational structures with networked, self-organizing, edge organizational forms in decisionmaking tasks (Ruddy, 2007). ELICIT requires teams of 17 members to collaborate in a network-centric environment to identify the who, what, where, and when of an adversary attack. Team members exchange information by posting information elements (called factoids) on common screens, or by sending these factoids directly to one another.

ELICIT certainly appears to be an interesting environment to investigate differences between hierarchical and edge organizations in a controlled, experimental manner. Researchers, however, also identified some limitations of ELICIT, including the large number of participants required, the lack of flexibility of the software, and the limited communication possibilities (e.g., Duncan \& Jobidon, 2008). PLATT has the advantage that fewer participants are required for experimental runs. In addition, researchers can configure the PLATT software themselves in many ways and, consequently, virtually any organizational form can be created and investigated. Moreover, in PLATT, participants are allowed to communicate with each other via e-mail, ensuring more realistic teamwork processes. Because of this, and because of other PLATT features (e.g., the individual Web sites), more diverse process and outcome variables can be measured using PLATT.

\section{Information Sharing and Team Virtuality}

Another software-based manipulation, related to the aforementioned one, pertains to the distribution of information within the team. The experimenter has the ability to define which role has access to which information on the Web sites. In addition, the experimenter determines who can view the shared workspace and who cannot. With these manipulations, it is possible to investigate the effects of shared information (information held by all group members) versus unshared information (information only held by one group member) on decision making in groups. Since the introduction of the biased sampling model of group discussion by Stasser and Titus (1985), an extensive line of research has investigated information pooling behaviors in groups. Many studies have shown that teams perform suboptimally because they spend more time discussing shared information than unshared information. In so doing, teams are not employing the informational advantage they should have over individuals (for a recent meta-analysis, see Mesmer-Magnus \& DeChurch, 2009).

The great majority of studies in this domain have used hidden profile tasks (e.g., select the best candidate) in which shared information supports an inferior alternative, 
whereas unshared information supports a superior option (Stasser \& Titus, 1985). The external validity of these tasks has been questioned (Mohammed \& Dumville, 2001), and the Mesmer-Magnus and DeChurch (2009) meta-analysis showed that the relationship between information sharing and team performance is partly caused by the use of these hidden profile tasks. In addition, in this paradigm, the primary dependent variables of interest have been the number of times particular information is mentioned and the quality of the decision made. Other team processes and team cognition have received far less attention. Researchers, therefore, have called for new directions within this research domain (e.g., Mesmer-Magnus \& DeChurch, 2009). PLATT could be a useful platform to facilitate this research, because scenarios can be made more realistic, and a broad range of process and outcome measurement possibilities are available (see below). In addition, in PLATT, different software-based manipulations are possible that make research in new directions feasible. One of the new proposed research directions, for example, pertains to virtual teams (Mesmer-Magnus \& DeChurch, 2009). This research should examine information sharing under various configurations of team virtuality (as determined by the team's use of virtual tools, the informational value of these tools, and the synchronicity of team member interactions; Kirkman \& Mathieu, 2005). PLATT can be configured to conduct this kind of research, because the experimenter can manipulate the level of team virtuality by, for example, varying communication media (e.g., e-mail, voice, and video-conferencing), the access to the digital shared workspace, and the nature of this digital shared workspace (e.g., a map of the area or a postings board).

\section{Multiteam Systems}

Another new direction in information sharing research proposed by Mesmer-Magnus and DeChurch (2009) concerns the area of multiteam systems. Recently, organizations have begun to employ this new form of work arrangement. In a multiteam system, two or more teams work interdependently toward the accomplishment of at least one collective distal goal, while at the same time pursuing different proximal goals (Mathieu et al., 2001). Team researchers have stressed the need for research in this area (e.g., Marks, DeChurch, Mathieu, Panzer, \& Alonso, 2005; Mesmer-Magnus \& DeChurch, 2009). In PLATT, it is possible to conduct this kind of research. Multiple teams can be defined, each with their own Web site and shared workspace. In addition, these teams may also have a workspace and Web site that are shared across teams. The experimenter can define which role within a team has the rights to communicate with members of other teams. This makes it possible to define different hierarchical levels: one level at which two or more teams primarily work to attain their own proximal goals, and a higher level at which representatives of these teams work toward the accomplishment of the common, more distal goal. All kinds of variations are imaginable, with different roles responsible for maintaining contact with the other teams, dif- ferent ways of framing the goal hierarchy, and different hierarchical structures.

\section{MEASURES}

PLATT offers the experimenter a broad range of measurement possibilities, both behavioral and self-report. In line with the plea of Cooke, Salas, Kiekel, and Bell (2004), these measurement possibilities are both automated and embedded. Automated behavioral measurement takes place as a result of logging by the scenario player, and online embedded questionnaires can be integrated in the scenario, enabling the measurement of team cognition. In this way, task disruptions due to measurement are reduced, experimenter measurement errors are minimized, and experimenter costs are lowered. Additionally, these real-time measurement possibilities allow for the measurement of the more dynamic aspects of team processes and team cognition (see, e.g., Cooke, Salas, CannonBowers, \& Stout, 2000)

\section{Behavioral}

As we mentioned previously, the scenario player creates a log file with detailed information on all of the scenario events and all of the actions that participants perform during task execution. On the basis of this information, different real-time unobtrusive measures can be constructed with help of the data analysis tool. The experimenter can, for example, construct measures concerning information processing (e.g., number of Web site visits, selective attention to information, intensity of shared workspace use) and communication (e.g., number of e-mails, use of subjects in headings, and content of communication). In addition, it is possible to measure behavioral indicators of relevant cognitive constructs (see, e.g., Cooke et al., 2000).

As an example, consider the use of behavioral indicators to measure the functioning of transactive memory systems (TMSs). A TMS consists of a set of distributed, individual memory systems that combines the knowledge possessed by particular members with a shared awareness of who knows what (Wegner, 1995). At the behavioral level, a TMS is indicated by directory updating, information allocation, and retrieval coordination (Wegner, 1995). Through directory updating, team members learn about each other's areas of expertise. Through information allocation and retrieval coordination, information is communicated to and retrieved from the teammate with the relevant area of expertise (see, e.g., Ellis, 2006; Hollingshead, 1998).

Whereas directory updating depends only on the content of the communication, information allocation and retrieval coordination depend on both communication content and communication flow. In PLATT, both communication content and communication flow are automatically recorded in the $\log$ files. As a result, to generate the behavioral indicators of a TMS, only communication content has to be coded. Subsequently, these codes can be inserted in the log file, and the data analysis tool can calculate the percentage of e-mails in which information was 
allocated to or retrieved from the team member with the relevant area of expertise. These measures then constitute the behavioral indicators of information allocation and retrieval coordination (cf. Ellis, 2006).

\section{Online Embedded Questionnaires}

The experimenter has the possibility to integrate hyperlinks to online questionnaires in the scenario. When the scenario reaches the specified time, these questionnaires are sent to the participants and are opened automatically, forcing them to fill out the questionnaire before they can continue with the task. Because the questionnaires are embedded, it is possible to get measures from different team members and measures across teams at precisely the same time. The timing and content of these questionnaires can be tuned to the events in the scenario.

This facility poses numerous possibilities. For example, to assess the team members' situation awareness (SA), one could use the embedded questionnaires to administer situation awareness global assessment technique (Endsley, 1995a) type measures. With these kinds of measures, the accuracy of individual SA can be assessed, but the measurements can also reflect the degree to which every team member possesses the SA that is required for his or her job (team SA; Endsley, 1995b) and the degree to which team members are in agreement with regard to aspects of the situation that are relevant to all team members (shared SA; Endsley \& Jones, 2001).

Other applications would include workload measurements, mental model measurements, and mood measurements, for example. Of course, this functionality of PLATT can also be used to administer questionnaires after teams have completed the scenario, to measure more static constructs and team outcomes such as satisfaction and cohesion.

\section{Outcome Measures}

The outcome measures are scenario specific. The experimenter has to develop a method to measure team performance objectively. In addition, the outcome measures should logically relate to the assignment that the team received and the processes in which the experimenter is interested (see, e.g., Smith-Jentsch, Johnston, \& Payne, 1998).

As an example, consider the performance measures in the military evacuation scenario. These measures consist of the quality of the route that the team has chosen and the number of errors that the team has made in planning the route. In order to arrive at these measures, the experimenter has to score a standardized form that the team has to fill out at the end of the scenario. On this form, teams have to (1) indicate which route they plan to use to evacuate the group of people; (2) mark on three separate time lines how they plan to make use of their infantry, engineer, and transportation units; and (3) specify how much time the evacuation will take, considering the chosen route and the planned employment of units.

The scenario has been constructed in such a way that all possible routes can be put in order from fastest to slowest, to make an objective comparison of routes in line with the assignment of the team possible. Due to events in the scenario, the most obvious routes eventually turn out to be the slowest ones, and the less obvious routes turn out to be the fastest. As a result, the better the teams process the events, the better the routes they will choose. The events are distributed in such a way that, independent of the route that teams choose, they always need to employ all of their units. This guarantees a similar possibility of making errors across different routes.

\section{EXPERIMENTS USING PLATT}

To date, PLATT has been used in four different research programs to investigate (1) the effects of threat on the performance of teams during complex problem-solving tasks, (2) self-synchronization in teams, (3) the effects of a serious gaming intervention on the performance of ad hoc teams, and (4) the effects of team structure on team decision making. Below, we briefly describe the scenarios that have been developed for these studies and the results that have been obtained. The results of these studies are described in more detail elsewhere (i.e., Kamphuis et al., 2008, 2009; Langelaan \& Keeris, 2008; Schraagen, Huis in't Veld, \& de Koning, 2010; Van Bezooijen, Vogelaar, \& Essens, 2009, 2010).

\section{Team Performance Under Threat}

The aforementioned military evacuation scenario was developed to investigate the effects of threat on the performance of teams during complex problem-solving tasks. In this research, special attention was paid to effects on information processing, communication, supporting behavior, leadership, and transactive memory. Two studies were conducted. In the first study, threat was manipulated external to the task, as a between-teams variable (Kamphuis et al., 2008). The second study used a $2 \times 2$ between-teams design and investigated to what extent a brief, transactive memory training intervention prior to task performance could mitigate the effects of threat on team performance (Kamphuis et al., 2009). Results of these studies show that in complex problem-solving environments, threat leads to a restriction in information processing and more controlling leadership. In addition, threat leads team members to shift from a team perspective to an individualistic focus, affecting transactive memory and teamwork processes. A brief transactive memory training intervention has the ability to moderate the negative effects of threat on team perspective, eventually resulting in better team performance (Kamphuis et al., 2008, 2009).

\section{Self-Synchronization in Teams}

Comparable military evacuation scenarios have been developed for research on self-synchronization (the undirected alignment of team members' actions with those of others in a network in light of overall objectives). Two studies were conducted in this line of research. The first study investigated the effects of leadership style on team situation models, self-synchronization, and coordination processes in teams (Van Bezooijen et al., 2009). Results indicated that participative leadership resulted in higher 
similarity of the team situation model when task complexity was low, whereas directive leadership resulted in higher similarity when task complexity was high. The second experiment investigated the effects of the presence or absence of synchronous groupware (i.e., the shared workspace) on self-synchronization in teams. Preliminary results of this study indicated that the use of synchronous groupware in teams does not necessarily improve synchronization and coordination processes (Van Bezooijen et al., 2010).

\section{Preparation of Ad Hoc Teams}

For research on the preparation of ad hoc expert teams, a crisis management scenario was developed. The goal of this research was to develop and test a game environment that can be used to enhance quick collaboration in professional ad hoc teams. The scenario had an alternate reality game-like nature. In this scenario, participants were confronted with a breakdown in the water supply, and they had to find out what caused this breakdown and solve the problem. In comparison with the military evacuation scenarios used in the aforementioned research programs, this scenario aimed to approach reality more closely by incorporating rich multimedia content, including video messages and realistic Web sites. In addition, instead of a digital map of the area, the shared workspace in this scenario consisted of a common mailbox that could be accessed via the individual workstations, and that was also projected on the wall. This made it possible, for example, to watch an important video message together. In a pilot study, ad hoc teams that had participated in this scenario were compared with ad hoc teams that had played different board games (e.g., Trivial Pursuit) together for the same length of time, on their performance on a second, unrelated team task (Langelaan \& Keeris, 2008). Results of this study indicated that the scenario approach, in which participants are forced to work together, seems to be a promising method to quicken the effective collaboration in ad hoc teams and enhance the building of trust between team members.

\section{Team Structure and Team Decision Making}

For research on the differences in decision making between hierarchical teams and networked teams, a scenario was created about an explosion in a tunnel through which a group of high-ranking politicians was about to pass. Teams had to decide as quickly and as accurately as possible what the likely cause of the incident was: an attack by Al Qaeda, an attack by antiglobalists, or an accident. In order to do this, each team member had received rolespecific training in one of these areas in order to be able to identify incidents linked to their area of expertise. In comparison with the aforementioned scenarios, this scenario was the least complex. No Web sites were used; all events were textual; and the only output required was a choice between the three alternatives. The shared workspace in this scenario consisted of a whiteboard with a decision tool in which the information elements supporting the different alternatives could be pasted. The experimental manipulation aimed to simulate the differences between hierarchical and networked teams and consisted of differences in team composition and task division, different decision rights, different communication media, and different information-sharing facilities (Schraagen et al., 2010). The results showed that networked teams were overall faster and more accurate in their decisions than were hierarchical teams. Networked teams also shared more knowledge with each other.

\section{CONCLUSION}

As the complexity of the workplace continually grows, teams will be confronted with complex cognitive tasks to a greater extent. Increasingly, they will have to perform these tasks as virtual teams in networked structures in close collaboration with other teams. Theories of teamwork and methods of measurement must keep pace with these developments to meet the demands from organizations for guidance on management and structuring of teamwork (cf. Salas et al., 2008). In response to these developments, we created a flexible software platform for research on team performance in complex environments, called PLATT.

PLATT should enable controlled experimental research into team planning, problem solving, and decision-making behavior in a complex, networked world. The development was guided by a set of seven requirements that we thought were pertinent to be able to conduct such research. The application of PLATT in a broad range of experiments in different research programs has shown that it has the ability to meet each of these requirements. Because of the chosen approach of creating a scenario-independent, flexible software architecture in which different researchspecific scenarios can be run, some requirements are met in the software architecture, and others are met in the specific scenarios. In all cases, however, the PLATT software architecture offers the possibility to fulfill the specified requirements.

First of all, PLATT allows researchers to investigate real team behavior. The formulated research model assists researchers in developing scenarios containing role specialization and task and goal interdependence. The software platform is flexible to such an extent that no matter how interdependence has been created in the scenarios, it can be run in PLATT.

Second, PLATT is suited to investigate higher level team processes that surface in complex environments. The complexity of the task can be influenced in multiple ways. A high information load can be attained by creating many events coming from different sources using different media. Furthermore, participants can be required to perform as many subtasks as desired. In addition, the typical scenarios in PLATT are characterized by unfamiliarity with the situation, absence of well-learned skills and procedures, ambiguity of information, and different possible methods to accomplish the task. Finally, the scenariodriven nature of PLATT makes it possible to create a dynamic environment in which the situation changes from time to time, necessitating participants to constantly adapt 
to new situations and alter existing plans. All in all, these characteristics bring about the higher level team processes of interest.

Third, PLATT offers a good degree of experimental control. All circumstances and events can be held constant. Because scenarios do not change in response to participants' actions, all teams face the same circumstances, and consequently, measures across teams can easily be compared. PLATT also offers excellent ways of controlled measurement through the logging of participants' actions and the possibility to administer online, embedded questionnaires.

Fourth, PLATT allows relatively convenient data collection. All scenarios that have been developed thus far could be played by participants without specific foreknowledge and without extensive training. Typically, teams would receive an instruction of about 30 min (partly by video) about the use of the participant interface and the specific task they had to perform. The scenarios that have been developed for experimental data collection typically take about half to three quarters of an hour to play. Evidently, it would also be possible to create longer or shorter scenarios. Overall, a complete experimental run would take, on average, $2 \mathrm{~h}$. For a complete experimental run, only one experimenter is necessary. There is no need for observers or for supporting players in the scenario.

Fifth, PLATT offers a broad range of team process measurement possibilities. Behavioral measures can be constructed with the help of the data analysis tool. In addition, the experimenter has the possibility to use online, embedded questionnaires. Both types of measures can be used to measure team cognition (either as an externalized process or as self-reported knowledge).

Sixth, the PLATT software allows a high degree of flexibility. This flexibility stems from the fact that (1) the software architecture is scenario independent, allowing researchers to develop their own scenarios; (2) the software itself has a modular setup, allowing researchers to remove and add components as they please; and (3) different configurations can be defined regarding communication possibilities and access rights, allowing configuration for multiple teams and multiple hierarchical levels.

Finally, PLATT has a good degree of usability. With regard to the use of PLATT by participants, the basic participant interface with different PLATT components on each tab hardly necessitates any explanation. Moreover, the user interfaces of the different participant applications (e.g., e-mail, Web browser, shared workspace) have proven to be very simple and intuitive as well. With regard to the use by experimenters, several aspects contribute to the usability of PLATT: No programming knowledge is required for scenario development; scenarios can be tested by using the accelerate function; a complete experiment can be configured in a single file; starting, running, and stopping of PLATT on every participant workstation can be controlled by the scenario player on the experimenter's workstation; and analyzing the log files is facilitated by the data analysis tool.

There are also some considerations for researchers intending to use PLATT. First, the development of a sce- nario takes time. The development of a basic scenario could be a matter of hours. Researchers who want to make use of the full array of possibilities that PLATT has to offer, however, should expect a greater time investment. This is an inherent consequence of the complexity that can be incorporated in PLATT. Writing a 4-h scenario for multiple teams, with lower level and higher level goals, using text, audio, and video events, dynamic Web sites, and different kinds of shared workspaces, will be more a matter of weeks than of days. However, different scenarios have already been developed, and, as the use of PLATT as a team research platform grows, more and more scenarios will be added to this collection. Researchers could draw existing scenarios from this pool and adapt these scenarios to their specific wishes.

Another issue, which surfaced during the first studies that used PLATT, is the process-outcome relationship. It proved difficult to establish a strong relationship between team processes and team performance. In organizational settings, this problem is not uncommon, because team performance may, in a large part, be determined by external circumstances and coincidence (cf. Smith-Jentsch et al., 1998). Because PLATT scenarios can be quite complex, the first studies using PLATT (e.g., Kamphuis et al., 2008) suffered from these same problems. To overcome them, we developed the aforementioned research model, which stimulates researchers to think of the scenario in terms of team processes. When researchers approach scenario development in this way, the process-outcome relationship will be established more easily (see, e.g., Kamphuis et al., 2009).

Finally, as described, the log files make it possible to construct a variety of measures of participants' behaviors. Although this possibility has a number of advantages, as we described previously, it should be used with caution. Researchers constructing measures on the basis of the log files are likely to regard these measures as behavioral indicators of some latent construct. However, it might be difficult to determine the validity of such a measure when it has not been used before. In such cases, it might be advisable to combine these behavioral measures with other (validated) measures to determine the validity of the behavioral measure.

All things considered, PLATT is a flexible platform that facilitates research into a wide array of team-related research questions. It provides researchers with an environment to investigate the complex issues that present-day teams face and has the ability to meet the demands of the future of team research.

\section{HARDWARE/ SOFTWARE REQUIREMENTS AND AVAILABILITY}

To be able to run PLATT, one PC for the scenario server and separate PCs or laptops for each participant are necessary. The PLATT software runs on computers with the Microsoft Windows XP operating system. Other software required is Windows XP Service Pack 2, the Microsoft .NET 3 framework, and the Visual J\# redistributable package. The computers must be connected by a network con- 
nection. Although the hardware demands of the software are not particularly high, it is recommended to use systems that smoothly run the Windows XP operating system and standard applications such as Microsoft Office. The software is expected to run on Microsoft Vista and newer versions of the .NET framework. PLATT is available to interested researchers. Requests should be addressed to the first author of this article.

\section{AUTHOR NOTE}

We thank Wilfried Post for his valuable contributions in originating the idea of PLATT. Address correspondence to W. Kamphuis, TNO Defence, Security and Safety, P.O. Box 23, 3769 ZG Soesterberg, The Netherlands (e-mail: wim.kamphuis@tno.nl).

\section{REFERENCES}

Alberts, D. S., \& Hayes, R. E. (2003). Power to the edge: Command and control in the information age. Washington, DC: Command and Control Research Program.

Bellifemine, F., Caire, G., Poggi, A., \& Rimassa, R. (2003). JADEA white paper. EXP: In Search of Innovation, 3(3), 6-19.

Brown, T. M., \& Miller, C. E. (2000). Communication networks in task-performing groups: Effects of task complexity, time pressure, and interpersonal dominance. Small Group Research, 31, 131-157.

Cannon-Bowers, J. A., Salas, E., \& Converse, S. A. (1993). Shared mental models in expert team decision making. In J. Castellan (Ed.), Current issues in individual and group decision making (pp. 221246). Hillsdale, NJ: Erlbaum.

Cooke, N. J., Salas, E., Cannon-Bowers, J. A., \& Stout, R. J. (2000). Measuring team knowledge. Human Factors, 42, 151-173.

Cooke, N. J., Salas, E., Kiekel, P. A., \& Bell, B. (2004). Advances in measuring team cognition. In E. Salas \& S. M. Fiore (Eds.), Team cognition (pp. 83-106). Washington, DC: American Psychological Association.

DunCan, M., \& Jobidon, M. E. (2008). Spontaneous role adoption and self-synchronization in edge organizations using the ELICIT platform. In Proceedings of the 13th International Command and Control Research and Technology Symposium [CD]. Washington, DC: Command and Control Research Program.

Durham, C. C., Locke, E. A., Poon, J. M. L., \& McLeod, P. L. (2000). Effects of group goals and time pressure on group efficacy, information-seeking strategy, and performance. Human Performance, 13, 115-138.

ELLIS, A. P. J. (2006). System breakdown: The role of mental models and transactive memory in the relationship between acute stress and team performance. Academy of Management Journal, 49, 576-589.

ENDSLEY, M. R. (1995a). Measurement of situation awareness in dynamic systems. Human Factors, 37, 65-84.

ENDSLEY, M. R. (1995b). Toward a theory of situation awareness in dynamic systems. Human Factors, 37, 32-64.

ENDSLEY, M. R., \& JONES, W. M. (2001). A model of inter- and intrateam situation awareness: Implications for design, training, and measurement. In M. McNeese, E. Salas, \& M. R. Endsley (Eds.), New trends in cooperative activities: Understanding system dynamics in complex environments (pp. 46-67). Santa Monica, CA: Human Factors and Ergonomics Society.

Gladstein, D. B., \& Reilly, N. P. (1985). Group decision making under threat: The tycoon game. Academy of Management Journal, 28, 613-627.

GRANLUND, R. (2002). Monitoring distributed teamwork training. Unpublished doctoral dissertation, Linköpings Universitet, Linköping, Sweden.

Hollenbeck, J. R., Sego, D. J., Ilgen, D. R., \& Major, D. A. (1991). Team Interactive Decision Exercise of Teams Incorporating Distributed Expertise (TIDE ${ }^{2}$ ): A program and paradigm for team research (Tech. Rep. No. RA 014-91-1). Arlington, VA: Office of Naval Research.

HollingsheAD, A. B. (1998). Retrieval processes in transactive memory systems. Journal of Personality \& Social Psychology, 74, 659-671.

Jentsch, F., Bowers, C., Compton, D., Navarro, G., \& Tait, T.
(1996). Team-Track: A tool for investigating tracking performance in teams. Behavior Research Methods, Instruments, \& Computers, 28, 411-417.

Johnson, D. W., \& Johnson, F. P. (1987). Joining together: Group theory and group skills (3rd ed.). Englewood-Cliffs, NJ: Prentice Hall.

Kamphuis, W., Gaillard, A. W. K., \& Vogelaar, A. L. W. (2008, April). Threat-rigidity effects on planning and decision making in teams. Paper presented at the 23rd Annual Conference of the Society for Industrial and Organizational Psychology, San Francisco, CA.

Kamphuis, W., Gaillard, A. W. K., \& Vogelaar, A. L. W. (2009, April). Teams under threat: The effects of transactive memory training. Paper presented at the 24th Annual Conference of the Society for Industrial and Organizational Psychology, New Orleans, LA.

Kamphuis, W., \& Houttuin, K. (2007). The planning task for teams (PLATT): An environment for research on planning and decision making in teams (Rep. No. TNO-DV 2007 IN528). Soesterberg, The Netherlands: TNO Defence, Security and Safety.

Kelly, J. R., Futoran, G. C., \& McGrath, J. E. (1990). Capacity and capability: Seven studies of entrainment of task performance rates. Small Group Research, 21, 283-314.

Kerr, N. L., Aronoff, J., \& Messé, L. A. (2000). Methods of small group research. In H. T. Reis \& C. M. Judd (Eds.), Handbook of research methods in social and personality psychology (pp. 160-189). New York: Cambridge University Press.

Kirkman, B. L., \& MathieU, J. E. (2005). The dimensions and antecedents of team virtuality. Journal of Management, 31, 700-718.

Kleinman, D. L., Serfaty, D., \& Luh, P. B. (1984). A research paradigm for multi-human decision-making. In Proceedings of the 1984 American Control Conference (pp. 6-11). San Diego: IEEE.

KLImoski, R., \& Mohammed, S. (1994). Team mental model: Construct or metaphor? Journal of Management, 20, 403-437.

LANGelaAn, S., \& KeERIS, E. (2008). Snel Samen Spelen [Building an ad hoc team using a new gaming concept] (Rep. No. TNO-DV 2008 A562). Soesterberg, The Netherlands: TNO Defence, Security and Safety.

Marks, M. A., DeChurch, L. A., Mathieu, J. E., Panzer, F. J., \& Alonso, A. (2005). Teamwork in multiteam systems. Journal of Applied Psychology, 90, 964-971.

Mathieu, J. E., Marks, M. A., \& Zaccaro, S. J. (2001). Multi-team systems. In N. Anderson, D. S. Ones, H. K. Sinangil, \& C. Viswesvaran (Eds.), Handbook of industrial, work and organizational psychology (Vol. 2, pp. 289-313). London: Sage.

MCC (1993). Management game manual. Amsterdam: MCC International.

Mesmer-Magnus, J. R., \& DeChurch, L. A. (2009). Information sharing and team performance: A meta-analysis. Journal of Applied Psychology, 94, 535-546.

Mohammed, S., \& Dumville, B. C. (2001). Team mental models in a knowledge framework: Expanding theory and measurement across disciplinary boundaries. Journal of Organizational Behavior, 22, 89-106.

RASKER, P. C. (2002). Communication and performance in teams. Wageningen, The Netherlands: Ponsen \& Looijen.

RASMUSSEN, J. (1986). Information processing and human-machine interaction: An approach to cognitive engineering. Amsterdam: NorthHolland.

RUDDY, M. E. (2006). Experiments in command and control within edge organizations: Final report (Rep. No. EBR06-0002). Washington, DC: Command and Control Research Program, Parity Communications Inc.

RudDy, M. E. (2007, June). ELICIT-The experimental laboratory for investigating collaboration, information-sharing and trust. Paper presented at the 12th International Command and Control Research and Technology Symposium, Newport, RI.

SaAvedra, R., Earley, P. C., \& Van Dyne, L. (1993). Complex interdependence in task-performing groups. Journal of Applied Psychology, 78, 61-72.

Salas, E., Cooke, N. J., \& Rosen, M. A. (2008). On teams, teamwork, and team performance: Discoveries and developments. Human Factors, 50, 540-547.

Salas, E., Dickinson, T. L., Converse, S. A., \& Tannenbaum, S. I. (1992). Toward an understanding of team performance and training. In W. Swezey \& E. Salas (Eds.), Teams: Their training and performance (pp. 3-29). Norwood, NJ: Ablex.

Schoelles, M. J., \& Gray, W. D. (2001). Argus: A suite of tools for 
research in complex cognition. Behavior Research Methods, Instruments, \& Computers, 33, 130-140.

SchraAgen, J. M., Huis in't Veld, M. A. A., \& de Koning, L. (2010). Information sharing during crisis management in hierarchical vs. network teams. Journal of Contingencies \& Crisis Management, 18, 117-127.

Smith-Jentsch, K. A., Johnston, J. H., \& Payne, S. C. (1998). Measuring team-related expertise in complex environments. In J. CannonBowers \& E. Salas (Eds.), Making decisions under stress: Implications for individual and team training (pp. 61-87). Washington, DC: American Psychological Association.

Stasser, G., \& Titus, W. (1985). Pooling of unshared information in group decision making: Biased information sampling during discussion. Journal of Personality \& Social Psychology, 48, 1467-1478.

Staw, B. M., Sandelands, L. E., \& Dutton, J. E. (1981). Threatrigidity effects in organizational behavior: A multilevel analysis. $A d-$ ministrative Science Quarterly, 26, 501-524.

Van Bezooijen, B. J. A., Vogelaar, A. L. W., \& Essens, P. J. M. D. (2009, April). The effect of leadership style on synchronization and coordination in networked teams. Paper presented at the 24th Annual Conference of the Society for Industrial and Organizational Psychology, New Orleans.

Van Bezooijen, B. J. A., Vogelaar, A. L. W., \& Essens, P. J. M. D.
(2010). Coordination in distributed teams. Manuscript in preparation.

VAN DER VEGT, G. S., \& VAN DE VlieRt, E. (2005). Effects of perceived skill dissimilarity and task interdependence on helping in work teams. Journal of Management, 31, 73-89.

VolKema, R. J. (1988). Problem complexity and the formulation process in planning and design. Behavioral Science, 33, 292-327.

Weaver, J. L., Bowers, C. A., Salas, E., \& Cannon-Bowers, J. A. (1995). Networked simulations: New paradigms for team performance research. Behavior Research Methods, Instruments, \& Computers, 27, 12-24.

WEGNER, D. M. (1995). A computer network model of human transactive memory. Social Cognition, 13, 319-339.

Wood, R. E. (1986). Task complexity: Definition of the construct. Organizational Behavior \& Human Decision Processes, 37, 60-82.

\section{NOTE}

1. This name had its origin in the first scenarios developed for the task environment, which were planning scenarios. In developing the environment, flexibility increased, as a result of which more types of tasks could be simulated. Nonetheless, we decided to adhere to the original name, since it had already been established.

APPENDIX

Excerpt of 30 Sec of an Actual Log File (in Dutch)

\begin{tabular}{ccccccc}
\hline Time & Actor & Action & Sender & Recipient & \multicolumn{1}{c}{ Subject } & \multicolumn{1}{c}{ Message Content } \\
\hline 16:05:45 & Logistiek & readEmail & Transporteenheid & Logistiek & $\begin{array}{l}\text { Informatie: } \\
\text { Positie }\end{array}$ & $\begin{array}{l}\text { De positie van onze eenheid is de plaats } \\
\text { Razgrad. U kunt onze eenheid inzetten } \\
\text { Transport- } \\
\text { om personen te evacueren naar Popintsi.| }\end{array}$ \\
& & & & & & \\
& & & & &
\end{tabular}

16:05:47 Logistiek openEmail Hoofdkwartier Logistiek Kennis:

Website

Bijgaand tref je een link aan naar een website waar je informatie over personele bezetting en de capaciteit van de transporteenheid en de genie-eenheid kunt vinden. (...)

16:05:47 Inlichtingen selectEmailTab

Inlichtingen openEmail

16:05:49 Logistiek selectWebTab

16:05:50 Logistiek selectSharedTab

16:05:51 Logistiek selectEmailTab

16:05:53 Inlichtingen receivedEmail

Lokale radiozender

Inlichtingen

Nieuwsflash: Vliegtuig neergestort

16:05:53 Logistiek receivedEmail Thuisfront Logistiek
Informatie: Rebellen tussen Golesh en Iskra

Tussen Golesh en Iskra worden met grote regelmaat groepen rebellen waargenomen. Het bereizen van deze weg brengt grote risico's met zich mee.|
Vanmorgen is een passagiersvliegtuig van Air Montegria neergestort tussen Leskovdol en Iskra. Reddingsploegen zijn onderweg, maar het wrak is moeilijk te bereiken om dat het gebied erg moerassig is. De autoriteiten kunnen nog niks zeggen over doden of gewonden. Over de oorzaak van het ongeluk is nog niets bekend.|

We gaan vandaag met z'n allen naar de dierentuin. We hoorden dat een van de tijgers een jonkie heeft en dat het een witte is. Dat schijnt heel bijzonder te zijn! De kinderen zijn hartstikke druk en kunnen niet meer wachten, dus ik ga ervandoor. Doei! | thuis:

Uitstapje

naar de

dierentuin 
APPENDIX (Continued)

\begin{tabular}{|c|c|c|c|c|c|c|}
\hline Time & Actor & Action & Sender & Recipient & Subject & Message Content \\
\hline $16: 05: 53$ & Operatiën & readEmail & $\begin{array}{l}\text { Infanterie- } \\
\text { eenheid }\end{array}$ & Operatiën & $\begin{array}{l}\text { Informatie: } \\
\text { Positie } \\
\text { en inzet } \\
\text { Infanterie- } \\
\text { eenheid }\end{array}$ & $\begin{array}{l}\text { De positie van onze eenheid is de } \\
\text { plaats Kriva Bara. ||U kunt een inzet } \\
\text { van onze eenheid inplannen om wegen } \\
\text { die niet veilig zijn (bijvoorbeeld van- } \\
\text { wege de aanwezigheid van rebellen, of } \\
\text { beschietingen) veilig te maken. U kunt } \\
\text { deze wegen pas weer gebruiken nadat u } \\
\text { ons heeft ingezet om ze te beveiligen. We } \\
\text { hebben altijd } 60 \text { MINUTEN nodig om } \\
\text { een groep rebellen of opstandelingen uit } \\
\text { te schakelen of te verdrijven. (...) }\end{array}$ \\
\hline $16: 05: 53$ & Operatiën & receivedEmail & Chefstaf & Operatiën & $\begin{array}{l}\text { Informatie: } \\
\text { Politiek }\end{array}$ & $\begin{array}{l}\text { In de Tweede Kamer is er momenteel een } \\
\text { discussie gaande over de duur van jullie } \\
\text { missie. Je wordt van de uitkomsten op de } \\
\text { hoogte gehouden. }\end{array}$ \\
\hline $16: 05: 54$ & Logistiek & clientrequest & & & & \\
\hline $16: 05: 54$ & webAgent & $\begin{array}{l}\text { webrequest } \\
10.0 .0 .2 \\
\text { extra_informatie_ } \\
\text { Logistiek.htm } \\
\text { True }\end{array}$ & & & & \\
\hline $16: 05: 57$ & Operatiën & sendEmail & Operatiën & Inlichtingen & & $\begin{array}{l}\text { lees tijdsduur nodig voor bev. We heb- } \\
\text { ben altijd } 60 \text { MINUTEN nodig om een } \\
\text { groep rebellen of opstandelingen uit te } \\
\text { schakelen of te verdrijven. }(. . .)\end{array}$ \\
\hline $16: 05: 57$ & Inlichtingen & receivedEmail & Operatiën & Inlichtingen & & $\begin{array}{l}\text { lees tijdsduur nodig voor bev. We heb- } \\
\text { ben altijd } 60 \text { MINUTEN nodig om een } \\
\text { groep rebellen of opstandelingen uit te } \\
\text { schakelen of te verdrijven. }(. . .)\end{array}$ \\
\hline $16: 05: 59$ & Inlichtingen & openEmail & $\begin{array}{l}\text { Lokale } \\
\text { radiozender }\end{array}$ & Inlichtingen & $\begin{array}{l}\text { Nieuwsflash: } \\
\text { Vliegtuig } \\
\text { neergestort }\end{array}$ & $\begin{array}{l}\text { Vanmorgen is een passagiersvliegtuig } \\
\text { van Air Montegria neergestort tussen } \\
\text { Leskovdol en Iskra. Reddingsploegen } \\
\text { zijn onderweg, maar het wrak is moeilijk } \\
\text { te bereiken om dat het gebied erg moer- } \\
\text { assig is. De autoriteiten kunnen nog niks } \\
\text { zeggen over doden of gewonden. Over } \\
\text { de oorzaak van het ongeluk is nog niets } \\
\text { bekend.| }\end{array}$ \\
\hline $16: 05: 59$ & webAgent & $\begin{array}{l}\text { webrequest } \\
10.0 .0 .2 \\
\text { extra_informatie_ } \\
\text { Logistiek.htm } \\
\text { True }\end{array}$ & & & & \\
\hline 16:06:01 & Operatiën & readEmail & Inlichtingen & Operatiën & Rebellen & $\begin{array}{l}\text { A: tussen } \mathrm{G} \text { en } \mathrm{U} \text { rebellen. Weg onveilig. } \\
\text { Bron: patrouille }\end{array}$ \\
\hline 16:06:01 & Operatiën & openEmail & Lokale burgers & Inlichtingen & $\begin{array}{l}\text { Informatie: } \\
\text { rebellen in } \\
\text { dal }\end{array}$ & $\begin{array}{l}\text { Een deel van de groep rebellen die in } \\
\text { de bergen tussen Golesh en Ustrem } \\
\text { zat, is afgedaald naar lager gebied en } \\
\text { bevindt zich op de weg tussen Leskov- } \\
\text { dol en Golesh. Deze weg is niet veilig } \\
\text { begaanbaar.| }\end{array}$ \\
\hline 16:06:01 & Logistiek & selectSharedTab & & & & \\
\hline $16: 06: 07$ & Logistiek & selectEmailTab & & & & \\
\hline 16:06:08 & Inlichtingen & openEmail & Operatiën & Inlichtingen & & $\begin{array}{l}\text { lees tijdsduur nodig voor bev. We heb- } \\
\text { ben altijd } 60 \text { MINUTEN nodig om een } \\
\text { groep rebellen of opstandelingen uit te } \\
\text { schakelen of te verdrijven. }(. . .)\end{array}$ \\
\hline $16: 06: 15$ & Operatiën & selectSharedTab & & & & \\
\hline
\end{tabular}

(Manuscript received August 25, 2009;

revision accepted for publication February 9, 2010.) 